\title{
Rose hip (Rosa canina $L$ ): A functional food perspective
}

\author{
Cui Fan, Callen Pacier, and Danik M. Martirosyan \\ Functional Food Center/Functional Food Institute, Dallas, TX, USA
}

Submission date: November 28, 2014; Acceptance date: December 22, 2014; Publication date:

December 24, 2014

Corresponding Author: Danik Martirosyan, PhD, Functional Food Center/Functional Food Institute, 7575 Frankford Rd, Suite 3527, Dallas, TX, 75252, USA

\begin{abstract}
:
Rose hip (Rosa canina L.) is the pseudo-fruit of the rose plant, which is widely known as a valuable source of polyphenols and vitamin C. Both in vivo and in vitro studies have demonstrated that this fruit exhibits anti-inflammatory, antioxidant, and antiobesogenic activities. The health benefits of Rose hip ( $\mathrm{RH}$ ) have been attributed to its wide range of bioactive compounds including the anti-inflammatory galactolipid: (2S)-1,2-di-O-[(9Z,12Z,15Z)-octadeca-9,12,15-trienoyl]-3-O$\beta$-D-galactopyranosyl glycerol (GOPO), vitamin C, phenolics, lycopene, lutein, zeaxanthin, and other carotenoids. As cyclooxygenase inhibitors, RH compounds may reduce the risk of cancer, heart disease, and various inflammatory conditions. The aim of this review is to present an overview of the functional, medical, and physiological properties of RH.
\end{abstract}

Keywords: Rosa canina, Rose hip, antioxidant, anti-inflammatory, GOPO, lycopene, and vitamin $\mathrm{C}$

\section{INTRODUCTION:}

Rose hip is the pseudo fruit of the rose plant. RH of some species, especially Rosa canina L. (dog rose), are considered valuable sources of polyphenols and vitamin C [1]. An interesting characteristic of $\mathrm{RH}$ is that its chemical composition differs depending on the cultivar, growing region, climate, maturity, cultivation practice, and storage conditions. Significant variations in organic acids, phenolics, sugars, water-soluble vitamins, and minerals of RH have been reported over the years by various researchers [2].

The physiological functions of Rosaceae fruits may be partly attributed to their abundance of phenolics. Phenolics possess a wide spectrum of biochemical activities including antioxidant, antimutagenic, and anti-carcinogenic properties. The total phenolic content of Rosa canina has been found to be $96 \mathrm{mg}$ GAE/g DW [2]. The physiological functions of Rosaceae fruits may also be partly attributed to their abundance of ascorbic acid. Ascorbic acid possesses a wide range of biochemical activities including antioxidant and anti-carcinogenic properties. The ascorbic acid content of RH was found to range from 140-1100mg/100ml, with the particular species Rosa 
canina having $880 \mathrm{mg} / 100 \mathrm{ml}[2,3]$. Those figures clearly show that $\mathrm{RH}$ is among the richest sources for ascorbic acid and phenolics, and may be the richest known fruit source $[2,4,5]$.

In addition to vitamin $\mathrm{C}, \mathrm{RH}$ contains other nutrients: carotenoids, tocopherol, bioflavonoids, tannins, pectin, sugars, organic acids, amino acids, and essential oils [2]. The nitrogen content of Rosa canina $\mathrm{RH}$ is $0.98 \%$ [2]. The concentrations of phosphorus and potassium are $4860 \mathrm{ppm}$ and 5467 ppm, respectively. The calcium and magnesium contents of RH are $2867 \mathrm{ppm}$ and 1254 ppm, while iron, copper, manganese and zinc concentrations are 27, 27, 56 and 30 ppm.

Other essential components of RH include essential fatty acids which are long chain, polyunsaturated fatty acids that humans must ingest since our bodies cannot synthesize them. Linoleic and $\alpha$-linolenic acids (ALA) are essential fatty acids which regulate blood pressure, blood viscosity, neural function, membrane fluidity, immune, inflammatory, and many other responses [2]. The total fat content of Rosa canina is $1.78 \%$ [2]. Fatty acid analysis showed that Rosa canina contains seven major fatty acids: lauric acid (12:0) with $4.80 \%$, palmitic acid (16:0) with $16.4 \%$, linoleic acid (cis-C18:2 $\omega 6)$ with $16.0 \%, \alpha$-linolenic acid (cis-C18:3 $\omega 3$ ) with 40.5\%, nonadecylic acid (19:0) with 4.74\%, cis-C19:1 $\omega 6$ with 5.79\%, and cis-C22:2 $\omega 6$ with $6.60 \%$ [2]. These results are in accordance with previous studies which found the dominant fatty acids in RH seeds to be linoleic and $\alpha$-linolenic acid $[2,6]$.

The galactolipid GOPO is another important compound of RH that deserves mentioning. This bioactive compound has study evidence to support both antitumor and anti-inflammatory activity with no known toxicity [7].

Although the evidence in favor of the use of Rosa canina is very promising, systematic studies are required to fully understand its possible contributions to human health before recommending its regular consumption. This review will present an overview of the functional, medical, and nutritional properties of RH.

\section{RETRIEVAL OF PUBLISHED STUDIES:}

Electronic searches were conducted across PubMed and Google Scholar databases. No language or other limitations were imposed. The keywords used for the search were: Rosa hips, Rosa canina, GOPO, vitamin C, lycopene, anti-inflammatory, antioxidants, carotenoids, osteoarthritis, cancer, and chronic disease. Reviews were initially selected and individual research papers were included later.

\section{NUTRITIONAL COMPOSITION OF ROSE HIP:}

Nutritional composition of wild RH is provided in table 1 [8]. As you can see, $\mathrm{RH}$ is rich in vitamin C, as it provides $426 \mathrm{mg}$ total ascorbic acid (vitamin C) in $100 \mathrm{~g} \mathrm{RH}$ fruit. Recommended Dietary Allowances (RDAs) for vitamin C is $90 \mathrm{mg}$ for men and 75mg for women [9]. Tolerable Upper Intake Levels (ULs) for Vitamin C is $2000 \mathrm{mg}$ per day for men and women [9]. RH also is rich in lycopene, as it contains $6.8 \mathrm{mg}$ lycopene in $100 \mathrm{~g}$ wild $\mathrm{RH}$ (Table 1). This review will focus on vitamin $\mathrm{C}$ and lycopene, in addition to GOPO, linoleic acid and $\alpha$-linoleic acid, due to their functional properties that provide health benefits and because of high content of those nutrients in RH. 
Table 1: Full Report (All Nutrients): Rose Hips, wild (Northern Plains Indians)

\begin{tabular}{|c|c|c|c|c|c|c|}
\hline Nutrient Proximates & Unit & $\begin{array}{l}\text { Value per } \\
100 \mathrm{~g}\end{array}$ & $\begin{array}{l}\text { Data } \\
\text { points }\end{array}$ & & Std. Error & $\begin{array}{l}1.0 \text { "cup" } \\
127.0 \mathrm{~g}\end{array}$ \\
\hline Water* & g & 58.66 & & 1 & -- & 74.5 \\
\hline Energy & kcal & 162 & & -- & -- & 206 \\
\hline Protein* & $\mathrm{g}$ & 1.6 & & 1 & -- & 2.03 \\
\hline Total lipid (fat)* & $\mathrm{g}$ & 0.34 & & 1 & -- & 0.43 \\
\hline Ash* & $\mathrm{g}$ & 1.18 & & 1 & -- & 1.5 \\
\hline Carbohydrate, by difference & $\mathrm{g}$ & 38.22 & & -- & -- & 48.54 \\
\hline Fiber, total dietary* & $\mathrm{g}$ & 24.1 & & 1 & -- & 30.6 \\
\hline Sugars, total $*$ & $\mathrm{~g}$ & 2.58 & & 1 & -- & 3.28 \\
\hline \multicolumn{7}{|l|}{ Minerals } \\
\hline Calcium, $\mathrm{Ca}^{*}$ & $\mathrm{mg}$ & 169 & & 1 & -- & 215 \\
\hline Iron, $\mathrm{Fe}^{*}$ & $\mathrm{mg}$ & 1.06 & & 1 & -- & 1.35 \\
\hline Magnesium, $\mathrm{Mg}^{*}$ & $\mathrm{mg}$ & 69 & & 1 & -- & 88 \\
\hline Phosphorus, $\mathrm{P}^{*}$ & $\mathrm{mg}$ & 61 & & 1 & -- & 77 \\
\hline Potassium, $\mathrm{K}^{*}$ & $\mathrm{mg}$ & 429 & & 1 & -- & 545 \\
\hline Sodium, $\mathrm{Na}^{*}$ & $\mathrm{mg}$ & 4 & & 1 & -- & 5 \\
\hline Zinc, $\mathrm{Zn} *$ & $\mathrm{mg}$ & 0.25 & & 1 & -- & 0.32 \\
\hline Copper, $\mathrm{Cu}^{*}$ & $\mathrm{mg}$ & 0.113 & & 1 & -- & 0.144 \\
\hline Manganese, $\mathrm{Mn}^{*}$ & $\mathrm{mg}$ & 1.02 & & 1 & -- & 1.295 \\
\hline \multicolumn{7}{|l|}{ Vitamins } \\
\hline $\begin{array}{l}\text { Vitamin } \mathrm{C} \text {, total ascorbic } \\
\text { acid* }\end{array}$ & $\mathrm{mg}$ & 426 & & 1 & -- & 541 \\
\hline Thiamin* & $\mathrm{mg}$ & 0.016 & & 1 & -- & 0.02 \\
\hline Riboflavin* & $\mathrm{mg}$ & 0.166 & & 1 & -- & 0.211 \\
\hline Niacin* & $\mathrm{mg}$ & 1.3 & & 1 & -- & 1.651 \\
\hline Pantothenic acid* & $\mathrm{mg}$ & 0.8 & & 1 & -- & 1.016 \\
\hline Vitamin B-6* & $\mathrm{mg}$ & 0.076 & & 1 & -- & 0.097 \\
\hline Vitamin A, RAE & $\hat{A} \mu g$ & 217 & & 1 & -- & 276 \\
\hline Carotene, beta* & $\hat{A} \mu g$ & 2350 & & 1 & -- & 2984 \\
\hline Carotene, alpha* & $\hat{A} \mu g$ & 31 & & 1 & -- & 39 \\
\hline Cryptoxanthin, beta* & $\hat{A} \mu g$ & 483 & & 1 & -- & 613 \\
\hline Vitamin A, IU & $\mathrm{IU}$ & 4345 & & 1 & -- & 5518 \\
\hline Lycopene* & $\hat{A} \mu g$ & 6800 & & 1 & -- & 8636 \\
\hline Lutein + zeaxanthin* & $\hat{A} \mu g$ & 2001 & & 1 & -- & 2541 \\
\hline
\end{tabular}




\begin{tabular}{|c|c|c|c|c|c|c|}
\hline Nutrient Proximates & Unit & $\begin{array}{l}\text { Value per } \\
100 \mathrm{~g}\end{array}$ & $\begin{array}{l}\text { Data } \\
\text { points }\end{array}$ & & Std. Error & $\begin{array}{l}1.0 \text { "cup" } \\
127.0 \mathrm{~g}\end{array}$ \\
\hline $\begin{array}{l}\text { Vitamin E (alpha- } \\
\text { tocopherol)* }\end{array}$ & $\mathrm{mg}$ & 5.84 & & 1 & -- & 7.42 \\
\hline Tocopherol, beta* & $\mathrm{mg}$ & 0.05 & & 1 & -- & 0.06 \\
\hline Tocopherol, gamma* & $\mathrm{mg}$ & 1.34 & & 1 & -- & 1.7 \\
\hline Tocopherol, delta* & $\mathrm{mg}$ & 0.14 & & 1 & -- & 0.18 \\
\hline Vitamin K (phylloquinone)* & $\hat{A} \mu g$ & 25.9 & & 1 & -- & 32.9 \\
\hline
\end{tabular}

*Nutrient Data Laboratory, ARS, USDA National Food and Nutrient Analysis Program, Wave 9j, 2005, Beltsville MD. (Modified)

GOPO AS AN ESSENTIAL BIOACTIVE COMPOUND IN ROSE HIP:

Larsen, Kharazmi, Christensen LP, and Christensen SB (2003) first isolated an anti-inflammatory agent with inhibitory effects on chemotaxis of human peripheral blood neutrophils in vitro from dried and milled fruits of Rosa canina [7]. This anti-inflammatory agent is a single compound identified as (2S)-1,2-di-O-[(9Z,12Z,15Z)-octadeca-9,12,15-trienoyl]-3-O- $\beta$-D-galactopyranosyl glycerol (GOPO), which may be responsible for the anti-inflammatory properties of RH powder (RHP) [7].

A number of clinical trials have shown positive effects of RHP on inflammation and arthritis as shown in Table 2. [10-12]. In a placebo controlled, double blind crossover clinical trial performed by Winther, Apel, and Thamsborg (2005), 94 patients with osteoarthritis of the hip or knee were randomized into a placebo or experimental (5g/day of RHP) group for 3 months [10]. A significant reduction in WOMAC (Western Ontario and McMaster Universities Osteoarthritis Index) pain (+/-) and consumption of 'rescue medication' after 3 weeks were observed [10]. Chrubasik C, Wiesner, Black, Müller-Ladner, and Chrubasik S (2008) conducted a one-year survey on the use of RHP, in which patients with acute exacerbation of chronic back pain experienced significant pain relief (though this study yielded positive results and will hopefully lead to future RH research, it deserves mentioning that the attrition rate was only $50 \%$, and no control group was used) [11]. In addition, another clinical trial by Willich et al. (2010) showed that moderate benefits were found for rheumatoid arthritis (RA) patients through significantly improved scores on the Health Assessment Questionnaire Disability Index (HAQ-DI) [12].

Schwager, Hoeller, Wolfram, and Richard (2011) further demonstrated that RHP and GOPO attenuate inflammatory responses in different cellular systems including mouse macrophages, peripheral blood leukocytes (PBLs), and chondrocytes [13]. Mouse macrophages were used to determine anti-inflammatory effects, PBLs allowed the measurement of anti-inflammatory effects on various cell populations, and chondrocytes and reticulocytes (in which RNA-synthesis can be visualized using dyes like new methylene blue) were used to delineate anabolic and catabolic events related to osteoarthritis (OA). Additionally, RHP and GOPO were found to down-regulate catabolic processes associated with OA or RA. These data provide more detailed molecular and biochemical basis for cartilage protection provided by RHP [13].

Although RH contains significant quantities of GOPO $(<0.1 \%)$, this concentration is not likely to account for all rheumatologic activity of RH. Other active principles are believed to act in 
concert to reduce the erosion of the extracellular matrix in joints or favor the rebuilding of cartilage [14].

Table 2: Health Benefits of the Bioactive Compound GOPO in Rose Hip

\begin{tabular}{|c|c|c|c|c|c|c|c|}
\hline Reference & Analysts & $\mathbf{N}$ & $\begin{array}{l}\text { Animal/ } \\
\text { patients }\end{array}$ & Duration & Interventin & Outcome & Studies \\
\hline $\begin{array}{l}\text { Larsen, } \\
2003 \text { [7] }\end{array}$ & $\begin{array}{l}\text { Dried and } \\
\text { milled } \\
\text { fruits of } \\
\text { RH }\end{array}$ & N/A & N/A, bioassay & N/A & N/A & $\begin{array}{l}\text { The galactolipid was } \\
\text { identified from Rosa } \\
\text { canina for its } \\
\text { inhibitory effect on } \\
\text { chemotaxis of } \\
\text { human peripheral } \\
\text { blood neutrophils in } \\
\text { vitro }\end{array}$ & Bioassay \\
\hline $\begin{array}{l}\text { Winther, } \\
2005[10]\end{array}$ & $\begin{array}{l}\text { RHP, } \\
\text { litozin }\end{array}$ & $\begin{array}{l}94 \\
\text { initial, } \\
80 \text { final }\end{array}$ & $\begin{array}{l}\text { Patients with } \\
\text { osteoarthritis of } \\
\text { the hip or knee }\end{array}$ & $\begin{array}{l}3 \\
\text { months }\end{array}$ & $\begin{array}{l}\text { Five } 0.5 \mathrm{~g} \\
\text { capsules of } \\
\text { RHP as } \\
\text { litozin twice } \\
\text { daily for } 3 \\
\text { months }\end{array}$ & $\begin{array}{l}\text { Alleviated } \\
\text { symptoms of } \\
\text { osteoarthritis and } \\
\text { reduced need for } \\
\text { 'medication'. }\end{array}$ & $\begin{array}{l}\text { Clinical } \\
\text { trial }\end{array}$ \\
\hline $\begin{array}{l}\text { Chrubasik } \\
2008 \text { [11] }\end{array}$ & $\begin{array}{l}\text { RH and } \\
\text { seed } \\
\text { powder, } \\
\text { litozin }\end{array}$ & $\begin{array}{l}152 \\
\text { initial, } \\
77 \text { final }\end{array}$ & $\begin{array}{l}\text { Patients with } \\
\text { acute } \\
\text { exacerbations of } \\
\text { chronic pain }\end{array}$ & $\begin{array}{l}54 \\
\text { weeks }\end{array}$ & $\begin{array}{l}\text { 5g capsules } \\
\text { RH as litozin } \\
\text { daily, which } \\
\text { contains } 3 \\
\text { mg of } \\
\text { galactolipid }\end{array}$ & $\begin{array}{l}\text { Endorsed as an } \\
\text { option in long-term } \\
\text { management of non- } \\
\text { specific low back } \\
\text { pain }\end{array}$ & $\begin{array}{l}\text { Clinical } \\
\text { trial }\end{array}$ \\
\hline $\begin{array}{l}\text { Willich, } \\
2010 \text { [12] }\end{array}$ & $\begin{array}{l}\text { standardiz } \\
\text { ed RHP }\end{array}$ & $\begin{array}{l}89 \\
\text { initial, } \\
74 \text { final }\end{array}$ & $\begin{array}{l}\text { Patients with } \\
\text { rheumatoid } \\
\text { arthritis (RA) }\end{array}$ & $\begin{array}{l}6 \\
\text { months }\end{array}$ & $\begin{array}{l}\text { Capsulated } \\
\text { RHP 5g } \\
\text { daily }\end{array}$ & $\begin{array}{l}\text { Improved HAQ-DI } \\
\text { patient scores }\end{array}$ & $\begin{array}{l}\text { Clinical } \\
\text { trial }\end{array}$ \\
\hline $\begin{array}{l}\text { Schwager, } \\
2011[13]\end{array}$ & RHP & N/A & $\begin{array}{l}\text { Cellular systems } \\
\text { (macrophages, } \\
\text { peripheral blood } \\
\text { leukocytes and } \\
\text { chondrocytes) }\end{array}$ & N/A & N/A & $\begin{array}{l}\text { RHP attenuates } \\
\text { inflammatory } \\
\text { responses in } \\
\text { different cellular } \\
\text { systems }\end{array}$ & $\begin{array}{l}\text { In vitro } \\
\text { studies }\end{array}$ \\
\hline
\end{tabular}

\section{LINOLEIC ACID AND $\alpha$-LINOLEIC ACID:}

Rose hip has proven potentially useful in the treatment of OA, one of the most common forms of arthritis. The inflammatory process is mediated by pro-inflammatory enzymes and cytokines, lowmolecular-weight compounds (such as eicosanoids), and the enzymatic degradation of tissues [15]. Several studies have related COX-2 to the inflammatory process [16]. This enzyme is an isoform of cyclooxygenase $(\mathrm{COX})$, which is responsible for catalyzing arachidonic acid to prostaglandin. The other isoform is cyclooxygenase-1 (COX-1, or prostaglandin-endoperoxide synthase (PTGS1)), which regulates angiogenesis; cell signaling, and the induction of platelet aggregation [15]. Organic solvent extracts of RH inhibit both COX-1 and COX-2. This activity is explained by bioassay-guided fractionations which isolate linoleic acid and ALA [17, 18]. 


\section{CAROTENOIDS IN ROSE HIP:}

Chromatographic analyses including thermal lens spectrometry (TLS) and high performance liquid chromatography (HPLC) revealed total carotenoids in Rosa canina fruits. The total carotenoids in the extracts are $\beta$-carotene, lycopene, rubixanthin, lutein, and zeaxanthin. HPLC analysis was then performed to quantify the above carotenoids. The investigators found roughly equal parts (around $20 \%$ ) of rubixanthin, $\beta$-carotene, lycopene, and lutein [19]. In another study, Horvath et al. (2012) identified six main carotenoids-epimers: neochrome, lutein, zeaxanthi, rubixanthin, lycopene, and $\beta, \beta$-carotene [20]. It also showed that the carotenoid extracts have anti-Helicobacer pylori, in vitro anti-tumor, multidrug resistance reversal, and radical scavenging activities [20].

\section{Lycopene}

Lycopene is a red, lipophilic antioxidant compound found in many fruits and vegetables. It is generally regarded as safe for human consumption, with one study finding no adverse effects at 30 mg per day for up to 8 weeks [21].

Lycopene is widely used to prevent heart disease, atherosclerosis, cataracts, asthma, and cancer of the prostate, breast, lung, bladder, ovaries, colon, and pancreas. Lycopene is also employed for treating human papilloma virus (HPV) infection, which is a major cause of uterine cancer. Despite these uses, there remains insufficient evidence for lycopene's utility in preventing the onset of these conditions [21]. Several groups reviewed the assertion that increased lycopene consumption could decrease prostate cancer risk in vitro, in vivo and by clinical trials (see Table 3) [22-26]. Despite promising preliminary evidence, this use of lycopene for prostate cancer remains questionable.

There is conflicting evidence regarding the effect of lycopene on heart disease. A number of in vitro studies have shown that lycopene can protect native low density lipoprotein (LDL) from oxidation and can suppress cholesterol synthesis [27]. Epidemiological studies yielded strong evidence for the role of lycopene in coronary heart disease (CHD) prevention [27], and women with higher levels of lycopene in their blood have a lower risk of heart disease [28]. However, other studies did not find any link between lycopene intake and the risk of heart attack and stroke in women [28].

Table 3: Effects of Lycopene on Prostate Cancer, Benign Prostatic Hyperplasia \& Breast Cancer

\begin{tabular}{lll}
\hline Reference & Inclusion Criteria & Outcome \\
\hline Ilic, 2011[22] & $\begin{array}{l}\text { Any quantity of lycopene, any duration } \\
\text { and in combination with any other } \\
\text { ingested supplements. }\end{array}$ & $\begin{array}{l}\text { Insufficient evidence to support the use of lycopene } \\
\text { in the prevention of prostate cancer. }\end{array}$ \\
Ilic, 2012[23] & $\begin{array}{l}\text { All published randomized controlled } \\
\text { trials (RCTs) comparing lycopene to } \\
\text { placebo (or other interventions) for the } \\
\text { treatment of BPH and prostate cancer. }\end{array}$ & $\begin{array}{l}\text { Significant decrease in prostate-specific antigen } \\
\text { levels in prostate cancer patients. However, } \\
\text { insufficient evidence for lycopene for the } \\
\text { prevention or treatment of BPH or prostate cancer. }\end{array}$ \\
Haseen, & $\begin{array}{l}\text { RCTs, nonrandomized controlled trials } \\
\text { or before-after studies involving } \\
\text { lycopene supplementation in any form } \\
\text { in prostate cancer patients, regardless of } \\
\text { their disease stage and treatment }\end{array}$ & $\begin{array}{l}\text { Insufficient evidence to recommend the use of } \\
\text { lycopene supplements in routine clinical practice } \\
\text { for prostate cancer patients. }\end{array}$ \\
\hline
\end{tabular}




\begin{tabular}{lll}
\hline Reference & Inclusion Criteria & Outcome \\
\hline $\begin{array}{l}\text { Holzapfel, } \\
2013[25]\end{array}$ & $\begin{array}{l}\text { In vitro studies, in vivo animal studies, } \\
\text { and clinical trials involving the potential } \\
\text { role of lycopene for the prevention and } \\
\text { therapy of prostate cancer. }\end{array}$ & $\begin{array}{l}\text { In vitro chemopreventive effects on prostate cancer } \\
\text { cells. Animal studies are inconsistent; the } \\
\text { preclinical data strongly suggests an } \\
\text { antitumorigenic acitivity of lycopene and its } \\
\text { different formulations, either alone or in } \\
\text { combination. }\end{array}$ \\
& $\begin{array}{l}\text { Long Island Breast Cancer Study } \\
\text { Project (1996-97) and genotype data on } \\
\text { catalase polymorphism. }\end{array}$ & $\begin{array}{l}\text { Fruit consumption found to prevent breast cancer, } \\
\text { there was no benefit to women already taking } \\
\text { supplements. This is especially true in women with } \\
\text { catalase loss-of-function polymorphisms. }\end{array}$ \\
\hline
\end{tabular}

\section{VITAMIN C:}

Vitamin C, also known as L-ascorbic acid, is an essential water-soluble vitamin. Humans, unlike most animals, are unable to synthesize vitamin $\mathrm{C}$ endogenously [29]. Vitamin $\mathrm{C}$ has several biological functions: it is required for the biosynthesis of collagen, L-carnitine, and norepinephrine. Vitamin $\mathrm{C}$ is also an important physiological antioxidant and has been shown to regenerate other antioxidants within the body, including alpha-tocopherol (vitamin E) [30].

Intake recommendations for vitamin $\mathrm{C}$ and other nutrients can be found in the Dietary Reference Intakes (DRIs), developed by the Food and Nutrition Board (FNB) at the Institute of Medicine (IOM) of the National Academies (formerly National Academy of Sciences) [9]. The recommended intake for vitamin $\mathrm{C}$ is $90 \mathrm{mg} /$ day for male adults and $75 \mathrm{mg} /$ day for female adults [9]. Fruits and vegetables are the best sources of vitamin $\mathrm{C}$.

\section{Cancer}

Vitamin $\mathrm{C}$ can limit the formation of carcinogens such as nitrosamines in vivo [31, 32], modulate immune response [31,33], and possibly attenuate oxidative damage (antioxidant function) that can lead to cancer [29]. There is a reverse association between dietary vitamin C intake and cancers of the lung, breast, colon or rectum, stomach, oral cavity, larynx or pharynx, and esophagus in most case-control studies [31, 33]. However, the evidence is inconsistent whether dietary vitamin $\mathrm{C}$ intake affects the risk of cancer. In addition, according to most clinical trials, vitamin $\mathrm{C}$ supplementation alone or with other nutrients provides no benefit for cancer prevention [30]. Furthermore, compared with controls, cancer patients have lower plasma concentrations of vitamin C [31].

Intravenous administration of high-dose vitamin $\mathrm{C}$ is widely used for cancer. Casciari et al. (2001) studied the effect of ascorbate on doxorubicin efficacy and found that low doses were cytoprotective while high doses increased cancer cell death [34]. Padayatty et al. (2006) compared oral vitamin $\mathrm{C}$ therapy with intravenous administration of the same dosage and proved that the intravenous methods yielded plasma concentrations about 25-fold higher [35]. A group of case reports and clinical trials support intravenous administration of vitamin $\mathrm{C}$ for cancer therapy (see Table 4). 
Table 4: Vitamin C and Cancer Treatment: Case Reports and Clinical Trials

\begin{tabular}{|c|c|c|c|c|c|}
\hline Reference & $\mathbf{N}$ & Patients & Duration & Intervention & Outcome \\
\hline $\begin{array}{l}\text { Padayatty, } \\
2006 \text { [35] }\end{array}$ & 1 & Renal tumor & 10 months & $\begin{array}{l}\text { IV } 65 \mathrm{~g} \text { twice/week for } 10 \\
\text { months (no chemotherapy } \\
\text { or radiation) }\end{array}$ & $\begin{array}{l}\text { The pulmonary metastatic } \\
\text { renal cancer spontaneously } \\
\text { regressed. }\end{array}$ \\
\hline $\begin{array}{l}\text { Padayatty, } \\
2006 \text { [35] }\end{array}$ & 1 & $\begin{array}{l}\text { A primary bladder } \\
\text { tumor with } \\
\text { multiple satellite } \\
\text { tumors around it }\end{array}$ & 4 years & $\begin{array}{l}\text { IV } 30 \mathrm{~g} \text { twice/week for } 3 \\
\text { months, then } 30 \mathrm{~g} / 1-2 \\
\text { months for } 4 \text { years (no } \\
\text { chemotherapy or } \\
\text { radiation) }\end{array}$ & $\begin{array}{l}\text { In good health with no } \\
\text { symptoms of recurrence or } \\
\text { metastasis } 9 \text { years after } \\
\text { diagnosis. }\end{array}$ \\
\hline $\begin{array}{l}\text { Padayatty, } \\
2006 \text { [35] }\end{array}$ & 1 & $\begin{array}{l}\text { A diffuse large B- } \\
\text { cell lymphoma at } \\
\text { Stage III }\end{array}$ & 19 months & $\begin{array}{l}\text { IV } 15 \mathrm{~g} \text { twice/week for } 2 \\
\text { months, then } 15 \mathrm{~g} \text { once to } \\
\text { twice/week for } 7 \text { months, } \\
\text { and then } 15 \mathrm{~g} / 2-3 \text { months } \\
\text { for about } 1 \text { year (no } \\
\text { chemotherapy; } 5 \text { weeks of } \\
\text { radiation therapy). }\end{array}$ & $\begin{array}{l}\text { In good health with no } \\
\text { clinical sign of lymphoma } 10 \\
\text { years after diagnosis. }\end{array}$ \\
\hline $\begin{array}{l}\text { Hoffer, } \\
2008 \text { [36] }\end{array}$ & $\begin{array}{l}24 \\
\text { initial, } \\
21 \\
\text { final }\end{array}$ & $\begin{array}{l}\text { Patients with a } \\
\text { solid tumor or } \\
\text { hematological } \\
\text { malignancy with } \\
\text { locally advanced, } \\
\text { metastatic or } \\
\text { recurrent disease }\end{array}$ & $\begin{array}{l}10-30 \\
\text { weeks }\end{array}$ & $\begin{array}{l}\text { IV } 0.4,0.6,0.9 \text { and } \\
1.5 \mathrm{~g} / \mathrm{kg} \text {, three times } \\
\text { weekly (chemotherapy } \\
\text { within the last } 2 \text { years; } \\
\text { but, none within } 4 \text { weeks } \\
\text { of study). }\end{array}$ & $\begin{array}{l}1.5 \mathrm{~g} / \mathrm{kg} \text { was recommended as } \\
\text { phase II dose, safe and free of } \\
\text { important toxicity in patients } \\
\text { with advanced untreatable } \\
\text { malignancies }\end{array}$ \\
\hline $\begin{array}{l}\text { Monti, } \\
2012 \\
{[37]}\end{array}$ & $\begin{array}{l}14 \\
\text { initial, } \\
9 \text { final }\end{array}$ & $\begin{array}{l}\text { Untreated patients } \\
\text { with metastatic } \\
\text { stage IV pancreatic } \\
\text { cancer }\end{array}$ & 8 weeks & $\begin{array}{l}\text { IV } 50,75 \text { and } 100 \mathrm{~g} \text { three } \\
\text { times/week with IV } \\
\text { gemcitabine }\left(1000 \mathrm{mg} / \mathrm{m}^{2}\right. \\
\text { over } 30 \text { minutes on day } 1 \text {, } \\
\text { once weekly for } 7 \text { weeks, } \\
\text { followed by a } 1 \text { week of } \\
\text { rest) and oral erlotinib } \\
\text { (100 mg per day). }\end{array}$ & $\begin{array}{l}\text { No increased toxicity was } \\
\text { observed with the addition of } \\
\text { ascorbic acid to gemcitabine } \\
\text { and erlotinib in pancreatic } \\
\text { cancer patients }\end{array}$ \\
\hline $\begin{array}{l}\text { Riordan, } \\
2005 \text { [38] }\end{array}$ & $\begin{array}{l}24 \\
\text { initial, } \\
11 \\
\text { final }\end{array}$ & $\begin{array}{l}\text { Late stage terminal } \\
\text { cancer patients } \\
\text { (mostly rectal } \\
\text { tumors with } \\
\text { metastatic disease). }\end{array}$ & 8 weeks & $\begin{array}{l}\text { IV } 150 \text { to } 710 \mathrm{mg} / \mathrm{kg} / \mathrm{day} \\
\text { for } 8 \text { weeks (prior } \\
\text { chemotherapy; but, not } \\
\text { within } 4 \text { weeks of study). }\end{array}$ & $\begin{array}{l}\text { The adverse effects were few } \\
\text { and minor; determined } \\
\text { relatively safe for terminal } \\
\text { cancer patients. }\end{array}$ \\
\hline $\begin{array}{l}\text { Drisko, } \\
2003 \text { [39] }\end{array}$ & 1 & $\begin{array}{l}\text { Advanced } \\
\text { epithelial ovarian } \\
\text { cancer with stage } \\
\text { IIIC papillary } \\
\text { serous } \\
\text { adenocarcinoma }\end{array}$ & 40 months & $\begin{array}{l}\text { IV } 60 \mathrm{~g} \text { twice/week during } \\
\text { chemotherapy, } 60 \mathrm{~g} \\
\text { once/week for a year, then } \\
60 \mathrm{~g} \text { every } 10 \text { to } 14 \text { days }\end{array}$ & $\begin{array}{l}\text { Maintained a normal CA- } \\
125^{*} \text { value; no recurrence } \\
3.3+\text { years after diagnosis. } \\
\text { Vitamin C may be a safe } \\
\text { method to improve } \\
\text { chemotherapy efficacy. }\end{array}$ \\
\hline $\begin{array}{l}\text { Drisko, } \\
2003 \text { [39] }\end{array}$ & 1 & $\begin{array}{l}\text { Advanced } \\
\text { epithelial ovarian } \\
\text { cancer with stage } \\
\text { IIIC mixed } \\
\text { papillary serous } \\
\text { and seromucinous } \\
\text { adenocarcinoma }\end{array}$ & 36 months & $\begin{array}{l}\text { IV } 60 \mathrm{~g} \text { daily for a week, } \\
\text { then } 60 \mathrm{~g} \text { twice/week for } \\
36 \text { months post-diagnosis } \\
\text { (prior chemotherapy; but, } \\
\text { not during IV Vitamin C } \\
\text { treatment). }\end{array}$ & $\begin{array}{l}\text { Maintained a normal CA- } \\
125^{*} \text { value; no recurrence } 3+ \\
\text { years after diagnosis. } \\
\text { Vitamin C may be a safe } \\
\text { method to improve } \\
\text { chemotherapy efficacy. }\end{array}$ \\
\hline $\begin{array}{l}\text { Jackson, } \\
1995[40]\end{array}$ & 1 & $\begin{array}{l}\text { A grade I } \\
\text { adenocarcinoma of } \\
\text { the pancreas with } \\
\text { metastasis }\end{array}$ & 13 weeks & $\begin{array}{l}398 \mathrm{~h} \text { IV infusions in } \\
\text { doses ranging from } 57.5 \\
\text { to } 115 \mathrm{~g} \text { over a } 13-\mathrm{week} \\
\text { period given in } 1000 \mathrm{~mL} \\
\text { of Ringer's Lactate** (no } \\
\text { chemotherapy or } \\
\text { radiation). }\end{array}$ & $\begin{array}{l}\text { No side effects and no tumor } \\
\text { progression six months after } \\
\text { diagnosis. A recurrence of } \\
\text { the tumor occurred after the } \\
\text { amount and frequency of IV } \\
\text { vitamin C was significantly } \\
\text { reduced. }\end{array}$ \\
\hline
\end{tabular}

\footnotetext{
* Protein tumor biomarker, **Non-pyrogenic IV solution
} 


\section{Cardiovascular Disease}

A number of epidemiological studies show that high intake of fruits and vegetable could reduce the risk of cardiovascular disease (CVD). However, results from most clinical intervention trials have failed to show beneficial effects of vitamin $\mathrm{C}$ supplementation on the primary or secondary prevention of cardiovascular disease (Table 5). In the Women's Antioxidant Cardiovascular Study, 8,171 women aged 40 years or older with a history of CVD were given $500 \mathrm{mg} /$ day vitamin $\mathrm{C}$ for a mean of 9.4 years. The study found no significant effect on CVD [41]. In addition, in the Physicians' Health Study II with 14,641 male participants aged 50 years or older $(5.1 \%$ of them had CVD), vitamin C supplementation of $500 \mathrm{mg} /$ day for a duration of 8 years had no effect on CVD [42].

Table 5: Effects of Vitamin C Supplementation on CVD

\begin{tabular}{|c|c|c|c|c|c|}
\hline Reference & $\mathrm{N}$ & Patients & Duration & Intervention & Outcome \\
\hline $\begin{array}{l}\text { Cook, } \\
2007[41]\end{array}$ & $\begin{array}{l}8171 ; \\
73 \% \text { mean } \\
\text { compliance }\end{array}$ & $\begin{array}{l}\text { Female, } 40 \text { years or } \\
\text { older with a history of } \\
\text { CVD or } 3 \text { or more } \\
\text { CVD risk factors }\end{array}$ & 9.4 years & $\begin{array}{l}500 \mathrm{mg} / \mathrm{d} \text { ascorbic } \\
\text { acid }\end{array}$ & $\begin{array}{l}\text { No overall effect } \\
\text { on cardiovascular } \\
\text { events }\end{array}$ \\
\hline $\begin{array}{l}\text { Sesso, } \\
2008[42]\end{array}$ & $\begin{array}{l}14641 ; \\
71 \% \text { adherence }\end{array}$ & $\begin{array}{l}\text { Male, } 50 \text { years or } \\
\text { older, including } 745 \\
\text { men }(5.1 \%) \text { with } \\
\text { prevalent CVD at } \\
\text { randomization }\end{array}$ & 8 years & $\begin{array}{l}500 \mathrm{mg} / \mathrm{d} \text { vitamin } \\
\mathrm{C}\end{array}$ & $\begin{array}{l}\text { Vitamin C } \\
\text { supplementation } \\
\text { did not reduce the } \\
\text { risk of CVD }\end{array}$ \\
\hline
\end{tabular}

\section{Common Cold}

In the 1970s, Linus Pauling suggested that vitamin C could successfully treat and/or prevent the common cold [43]. Although a number of controlled studies have been performed, the results have been controversial $[44,45]$. The evidence to date suggests that regular intakes of vitamin $\mathrm{C}$ at doses of at least $200 \mathrm{mg} /$ day does not reduce the risk of the common cold in the general population, but higher intakes might be helpful in people exposed to extreme physical exercise, cold environments, and those at risk of vitamin $\mathrm{C}$ inadequacy (such as the elderly and chronic smokers) $[45,46]$.

\section{IS ROSE HIP CONSIDERED A FUNCTIONAL FOOD OR FUNCTIONAL FOOD INGREDIENT?}

To answer this question we first have to define functional foods. As of today there is no generally recognized definition of functional foods. Even the Food and Drug Administration (FDA) has not yet defined functional foods. However, several other organizations have proposed definitions for this rapidly growing food category, including the International Food Information Council (IFIC), the Institute of Food Technologists and the Functional Food Center Inc.

The IFIC defines functional foods as those that include any "food or food component that may have health benefits beyond basic nutrition" [47]. In addition, a recent report of the Institute of Food Technologists considered functional foods as "food and food components that provide a health benefit beyond basic nutrition (for the intended population). These substances provide essential nutrients often beyond quantities necessary for normal maintenance, growth, and 
development, and/or other biologically active components that impart health benefits or desirable physiological effects" [48]. Furthermore, Dr. Martirosyan of the Functional Food Center (Dallas, TX, USA) recognizes functional foods as "natural or processed foods that contain known or unknown biologically active compounds; which, in defined amounts, provide a clinically proven and documented health benefit for the prevention, management, or treatment of chronic disease" [49].

At the recent 17th International Conference of the Functional Food Center (FFC) and 5th International Symposium of the Academic Society for Functional Food and Bioactive Components (ASFFBC) (which were held on November 18-19, 2014 at University of San Diego, San Diego, California, USA, organized jointly with USDA (United States Department of Agriculture), ARS (Agricultural Research Service)), Dr. Danik Martirosyan spoke about the importance of and the reasoning behind bringing the discovery, utilization, and control of bioactive components and functional foods as the main topic of the conference. He started his speech with the discussion of the "Functional Food Definition" according to the Functional Food Center. The definition of functional foods by the FFC (as stated above) was accepted by the audience and participants at the $10^{\text {th }}$ International Conference of the FFC at the University of California, Santa Barbara, USA on March 13-15, 2012.

The definition put forward by the FFC is different from others in that it accentuates bioactive compounds as the central part of functional foods. There can be one or many bioactive compounds in a given functional food and researchers are trying to find out the relationship in which they work together to be effective. Another important concept in the definition, according to Dr. Martirosyan, is the importance of the amount of bioactive compound(s) to convert an ordinary food into a functional food. Different amounts of bioactive compounds work in different situations and sometimes too much bioactive compound in a food can be toxic. In general a physiologic dose of bioactive compounds is regarded as safe. Concerning supraphysiological or pharmacological doses, safety aspects and health benefits must be documented. Therefore, it is crucial to have a thorough discussion on the use and control of bioactive compounds and functional foods.

According to the definition of functional foods by the FFC, RH can be considered a functional food ingredient if it meets certain criteria. The quantity of $\mathrm{RH}$ in given recipes needs to be substantial enough to provide health benefits, and that particular RH species must contain certain amounts of bioactive compounds such as vitamin C, GOPO, or lycopene, which will be effective for the prevention or management of certain chronic disease.

\section{FUNCTIONAL PROPERTIES OF ROSE HIP:}

\section{Anti-inflammatory and Immunomodulatory Activity}

The anti-inflammatory and immunomodulatory effects of $\mathrm{RH}$ have been well documented in numerous studies (Table 6). RH helps to alleviate symptoms of OA, RA and other diseases, as described below:

$\mathrm{OA}$ is the most common form of arthritis. It is a chronic condition in which cartilage breaks down. This causes the bones to rub against each other, leading to stiffness, pain, and loss of joint mobility. Recent studies found that inflammatory mediators (prostaglandins, chemokines, and cytokines) play an important role in the initiation and perpetuation of the OA process [50]. 
Abnormal joint stress activates intracellular signals via mechanoreceptors (ion channels and integrins) present at the surface of chondrocytes and osteocytes.

Table 6: Anti-inflammatory and Immunomodulatory Activity of Rose Hip

\begin{tabular}{|c|c|c|c|c|c|c|c|}
\hline Reference & Analysts & $\mathbf{N}$ & Subject & Duration & Intervention & Outcome & Studies \\
\hline $\begin{array}{l}\text { Christens } \\
\text { en, } 2008 \\
{[54]}\end{array}$ & $\begin{array}{l}\text { Rosa canina } \\
\text { RHP }\end{array}$ & $\begin{array}{l}306 \text { initial, } \\
287 \text { final }\end{array}$ & $\begin{array}{l}\text { Patients with } \\
\text { osteoarthritis }\end{array}$ & 3-4 months & $\begin{array}{l}5 \text { capsules of } \\
0.5 \mathrm{~g} \text { RHP twice } \\
\text { a day }\end{array}$ & $\begin{array}{l}\text { Pain reduction; } \\
\text { changes in pain } \\
\text { scores produced } \\
\text { a statistically } \\
\text { significant } \\
\text { combined ES* } \\
\text { of } 0.37\end{array}$ & $\begin{array}{l}\text { Meta- } \\
\text { analysis of } \\
3 \text { clinical } \\
\text { trials }\end{array}$ \\
\hline $\begin{array}{l}\text { Chrubasi } \\
\mathrm{k}, 2008 \\
{[11]}\end{array}$ & $\begin{array}{l}\text { The RH and } \\
\text { seed } \\
\text { powder, } \\
\text { litozin }\end{array}$ & $\begin{array}{l}152 \text { initial, } \\
77 \text { final }\end{array}$ & $\begin{array}{l}\text { Patients with } \\
\text { acute } \\
\text { exacerbation } \\
\text { s of chronic } \\
\text { pain }\end{array}$ & 54 weeks & $\begin{array}{l}5 \mathrm{~g} \text { RH as litozin } \\
\text { capsules daily, } \\
\text { which contains } 3 \\
\text { mg of } \\
\text { galactolipid }\end{array}$ & $\begin{array}{l}\text { Useful for long- } \\
\text { term } \\
\text { management of } \\
\text { non-specific low } \\
\text { back pain }\end{array}$ & $\begin{array}{l}\text { Clinical } \\
\text { trial }\end{array}$ \\
\hline $\begin{array}{l}\text { Warholm, } \\
2003 \text { [53] }\end{array}$ & $\begin{array}{l}\text { A } \\
\text { standardize } \\
\text { d RHP } \\
\text { produced } \\
\text { from the } \\
\text { seeds and } \\
\text { husks of } \\
\text { Rosa canina }\end{array}$ & $\begin{array}{l}100 \text { initial, } \\
96 \text { final }\end{array}$ & $\begin{array}{l}\text { Patients with } \\
\text { a diagnosis } \\
\text { of } \\
\text { osteoarthritis } \\
\text { of either the } \\
\text { hip or knee }\end{array}$ & 4 months & $\begin{array}{l}\text { Five } 0.5-g \\
\text { capsules of } \\
\text { standardized } \\
\text { RHP twice daily }\end{array}$ & $\begin{array}{l}\text { Improve hip } \\
\text { flexion and } \\
\text { reduce pain in } \\
\text { patients with } \\
\text { osteoarthritis }\end{array}$ & $\begin{array}{l}\text { Clinical } \\
\text { trial }\end{array}$ \\
\hline $\begin{array}{l}\text { Paydary, } \\
2012 \text { [55] }\end{array}$ & $\begin{array}{l}\text { Setarud } \\
\text { (IMOD) } \\
\text { (contain } \\
\text { extracts } \\
\text { from RH) }\end{array}$ & $6-600 * *$ & HIV Patients & 3 months & $\begin{array}{l}\text { IV } \\
\text { adminstration of } \\
125 \mathrm{mg}\end{array}$ & $\begin{array}{l}\text { Immunomodulat } \\
\text { ory effects; } \\
\text { improved } \\
\text { activity upon } \\
\text { lipid profile and } \\
\text { liver metabolism }\end{array}$ & $\begin{array}{l}\text { Clinical } \\
\text { trial }\end{array}$ \\
\hline $\begin{array}{l}\text { Sadigh- } \\
\text { Eteghad, } \\
2011[56]\end{array}$ & $\begin{array}{l}\text { RH hydro- } \\
\text { alcoholic } \\
\text { extract }\end{array}$ & 45 & $\begin{array}{l}\text { Male Wistar } \\
\text { rats }\end{array}$ & 4 weeks & $\begin{array}{l}\text { Oral gavage of } \\
\mathrm{RC} \text { fruit extract } \\
250-500 \mathrm{mg} / \mathrm{kg} / \mathrm{d}\end{array}$ & $\begin{array}{l}\text { Immunomodulat } \\
\text { ory effects }\end{array}$ & In Vitro \\
\hline $\begin{array}{l}\text { Kirkesko, } \\
2011 \text { [57] }\end{array}$ & $\begin{array}{l}\text { RHP, } \\
\text { litozin }\end{array}$ & $\begin{array}{l}30 \text { initial, } \\
28 \text { final }\end{array}$ & $\begin{array}{l}\text { Female } \\
\text { patients with } \\
\text { rheumatoid } \\
\text { arthritis }\end{array}$ & 28 days & $\begin{array}{l}\text { Seven } 750 \mathrm{mg} \\
\text { capsules of RHP } \\
\text { twice daily } \\
\text { (Litozin) }\end{array}$ & $\begin{array}{l}\text { No anti- } \\
\text { inflammatory or } \\
\text { antioxidant } \\
\text { effect; } \\
\text { concluded that } \\
10.5 \mathrm{~g} \text { daily dose } \\
\text { is insufficient }\end{array}$ & $\begin{array}{l}\text { Clinical } \\
\text { trial }\end{array}$ \\
\hline $\begin{array}{l}\text { Lattanzio, } \\
2011 \text { [58] }\end{array}$ & RH extract & 24 & $\begin{array}{l}\text { Male } \\
\text { Sprague- } \\
\text { Dawley rats }\end{array}$ & $\begin{array}{l}0- \\
210 \min * * *\end{array}$ & $\begin{array}{l}\text { Oral gavage } 100 \\
\text { and } 200 \mathrm{mg} / \mathrm{kg} \\
\text { of } \mathrm{RC} \text { extract }\end{array}$ & $\begin{array}{l}\text { Useful as } \\
\text { adjuvant for } \\
\text { inflammatory- } \\
\text { diseases }\end{array}$ & In Vivo \\
\hline $\begin{array}{l}\text { Willich, } \\
2010 \text { [12] }\end{array}$ & $\begin{array}{l}\text { A } \\
\text { standardize } \\
\text { d RHP } \\
\end{array}$ & $\begin{array}{l}89 \text { initial, } \\
74 \text { final }\end{array}$ & $\begin{array}{l}\text { Patients with } \\
\text { rheumatoid } \\
\text { arthritis (RA) }\end{array}$ & 6 months & $\begin{array}{l}\text { Capsulated RHP } \\
5 \mathrm{~g} \text { daily }\end{array}$ & $\begin{array}{l}\text { Improved HAQ- } \\
\text { DI patient scores }\end{array}$ & $\begin{array}{l}\text { Clinical } \\
\text { trial }\end{array}$ \\
\hline
\end{tabular}

*Reduction in pain calculated as effect size (ES), defined as the standardized mean difference (SMD)

**Phase I had 6, Phase II had 27, Phase III had 70, and Phase IV had 600.

$* * *$ Measured at $0,30,60,90,120,180$, and 210 min intervals

RHP was reported to inhibit chemotaxis of neutrophils and to lower C-reactive protein in both healthy volunteers and patients with osteoarthritis [51, 52]. Warholm, Skaar, Hedman, and Mølmen (2003) studied the impact of standardized RHP on OA patients; hip joint mobility and pain improved significantly in the treatment group compared with the placebo group [53]. Winther et al. (2005) conducted randomized clinical studies in OA patients and indicated that RHP 
reduced pain moderately and improved physical activity [10]. Christensen, Bartels, Altman, Astrup, and Bliddal (2008) reviewed 3 randomized controlled trials (RCTs) where 287 OA patients participated, and the results indicate that dry RHP seems to have a consistent, small to moderate efficacy on pain in OA patients in 3-4 months clinical trials [54].

RA is a chronic inflammatory autoimmune disorder that affects the joints in a polyarticular manner. Willich et al. (2010) performed a randomized trial to evaluate the efficacy of RHP on symptoms in patients with RA; the results indicated moderate clinical relevance in regards to improved HAQ-DI scores [12].

Other in vivo studies have pointed to the anti-inflammatory and immunomodulatory properties of Rosa canina extract [12, 55-58]. Lattanzio et al. (2011) found anti-inflammatory activity of RH extracts in a carrageenan-induced rat paw edema assay [58]. Sadigh-Eteghad et al. (2011) found $250-500 \mathrm{mg} / \mathrm{kg} \mathrm{RH}$ extract significantly increased the gamma globulin level, neutrophil and monocyte counts as well as phagocyte activity in comparison with the control rat groups [56].

\section{Antioxidant Properties}

Several studies have been conducted to evaluate the antioxidant properties of RH and its derivatives in vitro. Gao, Björk, Trajkovski, and Uggla (2000) investigated a crude extract prepared with 50\% ethanol from RHP and its phenolic, ascorbic, and lipophilic factions [3]. High antioxidant activity was found in all assays tested: the ferric-reducing antioxidant power (FRAP) assay, Trolox-equivalent antioxidant capacity (TEAC), lipid peroxidation (AMVN) and inhibition (AAPH) assay. The phenolic fraction made a major contribution to the antioxidant activity, but it was the lipophilic component that was the most effective based on the relation between total antioxidant capacity and antioxidant concentration [3].

Egea, Sánchez-Bel, Romojaro, and Pretel (2010) studied the total antioxidant activity of Rosa canina $\mathrm{RH}$ with five other fruits by measuring their ability to reduce the hydroxyl radical $(\mathrm{OH})$ and hydrogen peroxide $\left(\mathrm{H}_{2} \mathrm{O}_{2}\right)$, and their TEAC [59]. Total phenolics, ascorbic acid, and carotenoid content of the fruits were also analyzed. The phenolic and carotenoid content of Rosa canina was much higher than that of the other fruits analyzed. The ascorbic acid concentration of Rosa canina RH was also high, reflecting its higher activity on the TEAC assay and against $\mathrm{H}_{2} \mathrm{O}_{2}$ species. A collection analysis between each antioxidant and each phytonutrient was made; however, only phenolics and carotenoids showed a marginal correlation with the TEAC assay [59].

\section{Anti-obese Activities}

Rosa canina and the compound tiliroside (the principal constituent of its seeds) exhibit anti-obesity and anti-diabetic activities via the enhancement of fatty acid oxidation in the liver and skeletal muscle $[60,61]$.

\section{Other Properties}

The leaf extract of Rosa canina has an inhibitory effect against experimental diarrhea induced by castor oil in rodents [62]. Quercetin, isolated from a methanolic extract of $\mathrm{RH}$, has an inhibitory effect on melanogenesis in B16 melanoma cells [63]. Orally administering RH inhibits the skin pigmentation and tyrosinase activity in brown guinea pigs [63, 64]. 
The hydromethanol Rosa canina extract contributed to reducing the kidney and liver lipid peroxide to optimum level in rats that had been treated with ethylene glycol (EG) induced calcium oxide calculi in the kidneys. Rosa canina could potentially be used as a preventive agent against the formation of calcium oxide kidney stones [65].

\section{CONCLUSIONS:}

Rose hip is a good source of phytonutrients including vitamin $\mathrm{C}$ and lycopene, in addition to the anti-inflammatory agent GOPO. Due to its nutritional composition, Rose hip supplementation has many positive effects on certain chronic diseases including osteoarthritis, rheumatoid arthritis and cancer. There is also evidence to support anti-obesity and anti-diabetic activities from experimental studies on rodents. Though additional studies are required, Rose hip could be considered a functional food due to those health benefits.

List of Abbreviations: RH, Rose hip; ALA, $\alpha$-linolenic acids; GOPO, (2S)-1,2-di-O[(9Z,12Z,15Z)-octadeca-9,12,15-trienoyl]-3-O- $\beta$-D-galactopyranosyl glycerol; RHP, Rose hip powder; WOMAC, Western Ontario and McMaster Universities Osteoarthritis Index; RA, rheumatoid arthritis; HAQ-DI, Health Assessment Questionnaire Disability Index; PBLs, peripheral blood leukocytes; OA, osteoarthritis; COX, cyclooxygenase; COX-1, cyclooxygenase1; PTGS1, prostaglandin-endoperoxide synthase; TLS, thermal lens spectrometry; HPLC, high performance liquid chromatography; HPV, human papilloma virus; LDL, low density lipoprotein; CHD, coronary heart disease; DRI, Dietary Reference Intakes; FNB, Food and Nutrition Board; IOM, Institute of Medicine; CVD, cardiovascular disease; FDA, Food and Drug Administration; IFIC, International Food Information Council; FFC, Functional Food Center; ASFFBC, Academic Society for Functional Food and Bioactive Components; USDA, United States Department of Agriculture; ARS, Agricultural Research Service; RCTs, randomized controlled trials; FRAP, ferric-reducing antioxidant power; TEAC, Trolox-equivalent antioxidant capacity; EG, ethylene glycol; RDAs, Recommended Dietary Allowances; ULs, Tolerable Upper Intake Levels.

Competing Interests: The authors have no financial interests or any other conflicts of interest to disclose.

Authors' Contributions: All authors contributed to this review.

\section{REFERENCES:}

1. Chrubasik C, Roufogalis BD, Müller-Ladner U, Chrubasik S: A systematic review on the Rosa canina effect and efficacy profiles. Phytother Res 2008, 22(6):725-733.

2. Ercisli S: Chemical composition of fruits in some rose (Rosa spp.) species. Food Chemistry 2007, 104(4):1379-1384.

3. Gao X, Björk L, Trajkovski V, Uggla M: Evaluation of antioxidant activities of rosehip ethanol extracts in different test systems. J. Sci. Food Agric 2000, 80(14):2021-2027.

4. Kazankaya A, Koyuncu MA, and Balta F: Selection of rosehips naturally grown in the Lake Van region. In Proceedings of the Third National Horticulture Congress: 648-652 1999; Ankara, Turkey. 
5. Günes M: Pomological and phenological characteristics of promising rose hip (Rosa) genotypes. African Journal of Biotechnology 2010, 9(38):6301-6306.

6. Szentmihályi K, Vinkler P, Lakatos B, Illés V, Then M: Rose hip (Rosa canina L.) oil obtained from waste hip seeds by different extraction methods. Bioresource Technology 2002, 82(2):195-201.

7. Larsen E, Kharazmi A, Christensen LP, Christensen SB: An antiinflammatory galactolipid from rose hip (Rosa canina) that inhibits chemotaxis of human peripheral blood neutrophils in vitro. J. Nat. Prod2003, 66(7):994-995.

8. National Nutrient Database for Standard Reference [http://ndb.nal.usda.gov/ndb/foods/show/8256?fg=\&man=\&lfacet=\&count=\&max=\&sort= \&qlookup=\&offset=\&format=Full\&new=\&measureby=]

9. Institute of Medicine: Dietary Reference Intakes for Vitamin C, Vitamin E, Selenium, and Carotenoids. Washington, DC: National Academy Press; 2000.

10. Winther K, Apel K, Thamsborg G: A powder made from seeds and shells of a rose-hip subspecies (Rosa canina) reduces symptoms of knee and hip osteoarthritis: a randomized, double-blind, placebo-controlled clinical trial. Scand J Rheumatol2005, 34(4):302-308.

11. Chrubasik C, Wiesner L, Black A, Müller-Ladner U, Chrubasik S: A one-year survey on the use of a powder from Rosa canina lito in acute exacerbations of chronic pain. Phytother Res 2008, 22(9):1141-1148.

12. Willich SN, Rossnagel K, Roll S, Wagner A, Mune O, Erlendson J, Kharazmi A, Sörensen H, Winther K: Rose hip herbal remedy in patients with rheumatoid arthritis - a randomised controlled trial. Phytomedicine 2010, 17(2):87-93.

13. Schwager J, Hoeller U, Wolfram S, Richard N: Rose hip and its constituent galactolipids confer cartilage protection by modulating cytokine, and chemokine expression. BMC Complement Altern Med 2011, 11(1):105.

14. Schwager J, Richard N, Wolfram S: The galactolipid GOPO mediates beneficial effects of rose hip on arthritis by reducing chemokine and interleukine production in macrophages and chondrocytes. Int J Rheum Dis 2008, 11(Suppl 1):A96.

15. Dao TT, Chi YS, Kim J, Kim HP, Kim S, Park H: Synthesis and inhibitory activity against COX-2 catalyzed prostaglandin production of chrysin derivatives. Bioorg Med Chem Lett 2004, 14(5):1165-1167.

16. Cho H, Yun CW, Park WK, Kong JY, Kim KS, Park Y, Lee S, Kim BK: Modulation of the activity of pro-inflammatory enzymes, COX-2 and iNOS, by chrysin derivatives. Pharmacol Res2004, 49(1):37-43.

17. Jäger AK, Eldeen IMS, Van Staden J: COX-1 and -2 activity of rose hip. Phytother Res 2007, 21(12):1251-1252.

18. Jäger AK, Petersen KN, Thomasen G, Christensen SB: Isolation of linoleic and $\alpha$-linolenic acids as COX-1 and -2 inhibitors in rose hip. Phytother Res 2008, 22(7):982-984.

19. Hodisan T, Socaciu C, Ropan I, Neamtu G: Carotenoid composition of Rosa canina fruits determined by thin-layer chromatography and high-performance liquid chromatography. $\mathrm{J}$ Pharm Biomed Anal 1997, 16(3):521-528.

20. Horváth G, Molnár P, Radó-Turcsi E, Deli J, Kawase M, Satoh K, Tanaka T, Tani S, Sakagami H, Gyémánt N, Molnár J: Carotenoid composition and in vitro pharmacological activity of rose hips. Acta Biochim Pol 2012, 59(1):129-132.

21. Lycopene: MedlinePlus Supplements [http://www.nlm.nih.gov/medlineplus/druginfo/natural/554.html]

22. Ilic D, Forbes KM, Hassed C: Lycopene for the prevention of prostate cancer. Cochrane Database Syst Rev 2011, 11:1-24. 
23. Ilic D, Misso M: Lycopene for the prevention and treatment of benign prostatic hyperplasia and prostate cancer: a systematic review. Maturitas 2012, 72(4):269-276.

24. Haseen F, Cantwell MM, O'Sullivan JM, Murray LJ: Is there a benefit from lycopene supplementation in men with prostate cancer? A systematic review. Prostate Cancer Prostatic Dis 2009, 12(4):325-332.

25. Holzapfel N, Holzapfel B, Champ S, Feldthusen J, Clements J, Hutmacher D: The potential role of lycopene for the prevention and therapy of prostate cancer: from molecular mechanisms to clinical evidence. Int J Mol Sci 2013, 14(7):14620-14646.

26. Ahn J, Gammon MD, Santella RM, Gaudet MM, Britton JA, Teitelbaum SL, Terry MB, Nowell S, Davis W, Garza C, Neugut AI, Ambrosone CB: Associations between breast cancer risk and the catalase genotype, fruit and vegetable consumption, and supplement use. Am J Epidemiol 2005, 162(10):943-952.

27. Rao AV: Lycopene, tomatoes, and the prevention of coronary heart disease. Exp Biol Med (Maywood) 2002, 227(10):908-913.

28. Sesso HD, Buring JE, Norkus EP, Gaziano JM: Plasma lycopene, other carotenoids, and retinol and the risk of cardiovascular disease in women. Am J Clin Nutr 2004, 79(1):47-53.

29. Li Y, Schellhorn HE: New Developments and Novel Therapeutic Perspectives for Vitamin C. J Nutr 2007, 137(10):2171-2184.

30. Vitamin C - Health Professional Fact Sheet [http://ods.od.nih.gov/factsheets/VitaminC-HealthProfessional]

31. Carr AC, Frei B: Toward a new recommended dietary allowance for vitamin $\mathrm{C}$ based on antioxidant and health effects in humans. Am J Clin Nutr 1999, 69(6):1086-1107.

32. Hecht SS: Approaches to cancer prevention based on an understanding of N-nitrosamine carcinogenesis. Proc Soc Exp Biol Med 1997, 216(2):181-191.

33. Jacob RA, Sotoudeh G: Vitamin C function and status in chronic disease. Nutrition in Clinical Care 2002, 5(2):66-74.

34. Casciari JJ, Riordan NH, Schmidt TL, Meng XL, Jackson JA, Riordan HD: Cytotoxicity of ascorbate, lipoic acid, and other antioxidants in hollow fibre in vitro tumours. Br J Cancer 2001, 84(11):1544-1550.

35. Padayatty SJ, Riordan HD, Hewitt SM, Katz A, Hoffer LJ, Levine M: Intravenously administered vitamin $C$ as cancer therapy: three cases. CMAJ 2006, 174(7):937-942.

36. Hoffer LJ, Levine M, Assouline S, Melnychuk D, Padayatty SJ, Rosadiuk K, Rousseau C, Robitaille L, Miller WH: Phase I clinical trial of i.v. ascorbic acid in advanced malignancy. Annals of Oncology 2008, 19(11):1969-1974.

37. Monti DA, Mitchell E, Bazzan AJ, Littman S, Zabrecky G, Yeo CJ, Pillai MV, Newberg $\mathrm{AB}$, Deshmukh S, Levine $\mathrm{M}$ : Phase I evaluation of intravenous ascorbic acid in combination with gemcitabine and erlotinib in patients with metastatic pancreatic cancer. PLoS ONE 2012, 7(1):e29794.

38. Riordan HD, Casciari JJ, González MJ, Riordan NH, Miranda-Massari JR, Taylor P, Jackson JA: A pilot clinical study of continuous intravenous ascorbate in terminal cancer patients. Puerto Rico Health Sciences Journal 2005, 24(4):269-276.

39. Drisko JA, Chapman J, Hunter VJ: The use of antioxidants with first-line chemotherapy in two cases of ovarian cancer. J Am Coll Nutr 2003, 22(2):118-123.

40. Jackson JA, Riordan HD, Hunninghake RE: High-dose intravenous vitamin C and longtime survival of a patient with cancer of the head of the pancreas. J Orthomol 1995, 10:8788.

41. Cook NR, Albert CM, Gaziano JM, Zaharris E, MacFadyen J, Danielson E, Buring JE, Manson JE: A randomized factorial trial of vitamins $\mathrm{C}$ and $\mathrm{E}$ and beta carotene in the 
secondary prevention of cardiovascular events in women: results from the women's antioxidant cardiovascular study. Arch Intern Med 2007, 167(15):1610-1618.

42. Sesso HD, Buring JE, Christen WG, Kurth T, Belanger C, MacFadyen J, Bubes V, Manson JE, Glynn RJ, Gaziano JM: Vitamins E and C in the prevention of cardiovascular disease in men: the physicians' health study II randomized controlled trial. JAMA 2008, 300(18):2123-2133.

43. Pauling L: The significance of the evidence about ascorbic acid and the common cold. Proc Natl Acad Sci U.S.A. 1971, 68(11):2678-2681.

44. Douglas RM, Hemilä H: Vitamin C for preventing and treating the common cold. PLoS Med 2005, 2(6):e168.

45. Douglas RM, Hemilä H, Chalker E, Treacy B: Vitamin C for preventing and treating the common cold. Cochrane Database Syst Rev 2007, 3:1-74.

46. Wintergerst ES, Maggini S, Hornig DH: Immune-enhancing role of vitamin C and zinc and effect on clinical conditions. Ann Nutr Metab 2006, 50(2):85-94.

47. 2009 Functional Foods/Foods For Health Consumer Trending Survey Executive Summary: IFIC Foundation [http://www.foodinsight.org/2009_Functional_Foods_Foods_For_Health_Consumer_Tren ding_Survey_Executive_Summary]

48. Functional Foods: Opportunities and Challenges [http://www.ift.org/knowledge-center/read-ift-publications/science-reports/expertreports.aspx]

49. Martirosyan DM: Definition of functional food. Introduction to Functional Food Science. Volume 1. 2nd edition. Dallas, TX: Food Science Publisher; 2013:26.

50. Berenbaum F: Osteoarthritis as an inflammatory disease (osteoarthritis is not osteoarthrosis!). Osteoarthritis and Cartilage 2013, 21(1):16-21.

51. Kharazmi A, Winther K: Rose hip inhibits chemotaxis and chemiluminescence of human peripheral blood neutrophils in vitro and reduces certain inflammatory parameters in vivo. Inflammopharmacology 1999, 7(4):377-386.

52. Winther K, Rein E, Kharazmi A: The anti-inflammatory properties of rosehip. Inflammopharmacology 1999, 7(1):63-68.

53. Warholm O, Skaar S, Hedman E, Mølmen HM: The effects of a standardized herbal remedy made from a subtype of Rosa canina in patients with osteoarthritis: a double-blind, randomized, placebo-controlled clinical trial. Current Therapeutic 2003, 64(1):21-31.

54. Christensen R, Bartels EM, Altman RD, Astrup A, Bliddal H: Does the hip powder of Rosa canina (rosehip) reduce pain in osteoarthritis patients? -a meta-analysis of randomized controlled trials. Osteoarthr Cartil 2008, 16(9):965-972.

55. Paydary K, Emamzadeh-Fard S, Khorram Khorshid HR, Kamali K, SeyedAlinaghi S, Mohraz M: Safety and efficacy of Setarud (IMOD TM) among people living with HIV/AIDS: a review. Recent Pat Antiinfect Drug Discov 2012, 7(1):66-72.

56. Sadigh-Eteghad S, Tayefi-Nasrabadi H, Aghdam Z, Zarredar H, Shanehbandi D, Khayyat L, Seyyed-Piran SH: Rosa canina L. fruit hydro-alcoholic extract effects on some immunological and biochemical parameters in rats. Bioimpacts 2011, 1(4):219-224.

57. Kirkeskov B, Christensen R, Bügel S, Bliddal H, Danneskiold-Samsøe B, Christensen LP, Andersen JR: The effects of rose hip (Rosa canina) on plasma antioxidative activity and Creactive protein in patients with rheumatoid arthritis and normal controls: a prospective cohort study. Phytomedicine 2011, 18(11):953-958.

58. Lattanzio F, Greco E, Carretta D, Cervellati R, Govoni P, Speroni E: In vivo antiinflammatory effect of Rosa canina L. extract. J Ethnopharmacol 2011, 137(1):880-885. 
59. Egea I, Sánchez-Bel P, Romojaro F, Pretel MT: Six edible wild fruits as potential antioxidant additives or nutritional supplements. Plant Foods Hum Nutr 2010, 65(2):121129.

60. Nagatomo A, Nishida N, Matsuura Y, Shibata N: Rosehip extract inhibits lipid accumulation in white adipose tissue by suppressing the expression of peroxisome proliferator-activated receptor gamma. Prev Nutr Food Sci 2013, 18(2):85-91.

61. Ninomiya K, Matsuda H, Kubo M, Morikawa T, Nishida N, Yoshikawa M: Potent antiobese principle from Rosa canina: structural requirements and mode of action of transtiliroside. Bioorg Med Chem Lett 2007, 17(11):3059-3064.

62. Mandade RJ, Choudhury A, Harsulkar A, Wakade R: Role of the Rosa canina L. leaf extract as an antidiarrheal drug in rodents. Indian J Pharmacol 2011, 43(3):316-319.

63. Fujii T, Saito M: Inhibitory effect of quercetin isolated from rose hip (Rosa canina L.) against melanogenesis by mouse melanoma cells. Biosci Biotechnol Biochem 2009, 73(9):1989-1993.

64. Fujii T, Ikeda K, Saito M: Inhibitory effect of rose hip (Rosa canina L.) on melanogenesis in mouse melanoma cells and on pigmentation in brown guinea pigs. Biosci Biotechnol Biochem 2011, 75(3):489-495.

65. Tayefi-Nasrabadi H, Sadigh-Eteghad S, Aghdam Z: The effects of the hydroalcohol extract of Rosa canina L. fruit on experimentally nephrolithiasic Wistar rats. Phytother Res 2012, 26(1):78-85. 